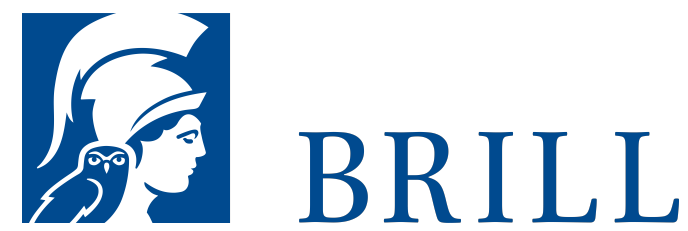

\title{
Heinz Nixdorf
}

Der Sportsmann und der Förderer des Sports. Ein Stück Biographie

Author: Volker Werb

Der damalige Bundespräsident, Richard von Weizsäcker, hat Heinz Nixdorf (1925-1986) als den ,ideenreichsten und erfolgreichsten Unternehmer der Bundesrepublik“ Deutschland gewürdigt. Dieser hatte als Werkstudent mit Hilfe eines Kredits seine erste elektronisch gesteuerte Rechenmaschine konstruiert und in den folgenden drei Jahrzehnten seine „Nixdorf Computer AG“" zu einer „Paradefirma der deutschen Wirtschaft ausgebaut“. So lautete die Begründung bei der Wahl zum „Manager des Jahres 1985“. Der Computerpionier hatte in seinem profitablen Unternehmen weltweit ca. 23.0oo Arbeitsplätze geschaffen, davon ca. 8.00o am Firmensitz in Paderborn. Ein Leben ohne Begeisterung für Wettbewerb und Wettkampf mit dem Ziel, bessere und beste Leistungen zu erreichen, war für Heinz Nixdorf nicht vorstellbar. Mit dieser Grundeinstellung war er im Beruf und ebenso im Sport außergewöhnlich aktiv. Was er selbst an Sport trieb, und all das, was er an beispielhafter Sportförderung bewirkte, ist mithin integraler Bestandteil seiner Biographie. Zahlreiche Abbildungen, überwiegend aus privatem

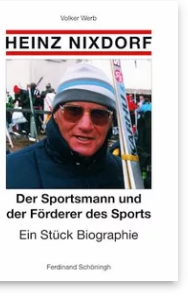

Pages: $6 \circ 8$

Seiten, $70 \mathrm{~s} / \mathrm{w}$ und 30 farb. Abb.

Language:

German

Subjects:

General, History

Publisher: Brill |

Schöningh

Hardback

Publication date: 24 Oct 2007

ISBN: $978-3^{-}$

506-71330-8

List price

USD $\$ 48.00$ Besitz, lassen ein anschauliches Bild der vielseitigen Persönlichkeit entstehen. Als einer der vertrauten Freunde von Heinz Nixdorf will der Autor nicht lediglich Erinnerung wach halten, sondern mit Hilfe weiterer Freunde und Zeitzeugen quasi ein Denkmal für die Paderborner Sportwelt errichten. Diese soll ein... 
For more information see brill.com

Order information: Order online at brill.com +44330 333 0049 | customerservices@brill.com Submission information: brill.com/authors

Titles published by Brill | Fink, Brill | mentis or Brill | Schöningh: +49(o)715413279216| brill@brocom.de 